\title{
OBJEKTIVITAS TIGA MEDIA SIBER INDONESIA: STUDI KONTEN BERITA KONFLIK ISRAEL-PALESTINA
}

\author{
Indra Prawira, Rahmat Edi Irawan, dan Karen \\ Departemen Komunikasi, Universitas Bina Nusantara, Jakarta, Indonesia \\ E-mail: iprawira@binus.edu
}

\begin{abstract}
ABSTRAK. Konflik Israel-Palestina yang berlangsung pada bulan Mei 2021 menjadi berita internasional yang menarik perhatian masyarakat Indonesia. Media di Indonesia memberitakan konflik Israel-Palestina sebagai berita utama seiring warga yang melakukan pergerakan sosial dalam membantu korban konflik. Gerakan dukungan terhadap warga Palestina juga dilakukan secara politis oleh kepala daerah, politisi Dewan Perwakilan Rakyat-DPR dan Presiden Republik Indonesia, Joko Widodo yang menunjukkan kebijakan politik internasional Indonesia. Pemerintah, politisi dan organisasi masyarakat tampil di media dalam menunjukkan dukungan mereka terhadap kedaulatan Palestina. Namun, terdapat masyarakat Indonesia yang juga mendukung Israel. Penelitian ini bertujuan untuk menginvestigasi objektifitas media di Indonesia dalam memberitakan konflik Israel-Palestina. Studi ini mengadopsi konsep objektifitas media terhadap berita dari tiga media siber di Indonesia yaitu okezone.com, detik.com, dan kompas.com. Metode yang diterapkan adalah penelitian analisis konten kuantitatif terhadap berita yang dipublikasikan tiga media siber nasional Indonesia tersebut selama bulan Mei-Juni 2021. Terdapat 225 sample berita yang didapat secara acak dari 675 berita yang terkumpul. Uji validitas dan reliabilitas intercoder menunjukkan hasil memuaskan dengan rata-rata nilai Cronbach Alpha 0.875. Hasil penelitian ini menunjukkan bahwa tiga media siber Indonesia yang diteliti aktif memberitakan konflik Israel-Palestina dengan frekuensi berita yang tinggi. Ketiga media mengikuti objektifitas berdasarkan kepentingan publik yang sejalan dengan objektifitas pemerintah, dan media. Media siber Indonesia mengikuti objektifitas yang berdasar pada opini profesional dengan menampilkan peliputan yang informatif, sementara objektifitas media bersifat parsial mendukung kedaulatan Negara Palestina.
\end{abstract}

Kata Kunci: Kebijakan politik internasional; konflik Israel-Palestina; media siber Indonesia; objektifitas media

\section{THE OBJECTIVITY OF THREE INDONESIAN CYBER MEDIA: STUDY OF NEWS CONTENT IN THE ISRAEL-PALESTINE CONFLICT}

\begin{abstract}
The Israeli-Palestinian conflict in May 2021 became international news that attracted the attention of the Indonesians. Media in Indonesia reported on the Israeli-Palestinian conflict as headlines as people carried out social movements to help victims of the conflict. Regional heads, politicians from the House of Representatives-DPR, and the President of the Republic of Indonesia, Joko Widodo, who showed Indonesia's international political policies, also carried out the support for the Palestinians politically. Governments, politicians, and civil society organizations appear in the media to support Palestinian sovereignty. However, there are Indonesians who support Israel in this conflict. This study aims to investigate the objectivity of the media in Indonesia in reporting the Israeli-Palestinian conflict. This study adopts the concept of media objectivity towards news from three cyber media in Indonesia, namely okezone.com, detik.com, and kompas.com. The method applied is quantitative content analysis research on the news published by the three Indonesian national cyber media during May-June 2021. There are 225 news samples obtained randomly from the 675 news collected. The validity and intercoder reliability tests showed satisfactory level with an average Cronbach Alpha value of 0.875. This study indicates that the three Indonesian cyber media actively report on the Israeli-Palestinian conflict with high news frequency. The three media follow objectivity based on the public interest, which have the same objetivity with Government and media objectivity. Indonesian cyber media follows objectivity based on a professional opinion by presenting informative coverage, while media objectivity is partial in favor of the sovereignty of the Palestinian state.
\end{abstract}

Keywords: Content analysis; Israeli-Palestenian conflict; international political policy; media objectivity PENDAHULUAN

Konflik Israel-Palestina menjadi berita internasional yang menarik perhatian masyarakat Indonesia. Informasi mengenai konflik IsraelPalestina menghiasi berbagai platform media di Indonesia baik lokal maupun nasional. Seiring dengan beredarnya berita konflik tersebut, terdapat gerakan sosial yang tersebar di seluruh Indonesia untuk membantu warga Palestina yang menjadi korban. Gerakan sosial tersebut berupa penggalangan dana baik melalui lembaga pemerintah daerah seperti yang dilakukan Pemerintah Kota Padang (Sasongko, 2021), maupunmelalui lembaga-lembagaindependen seperti ACT.id ataupun kasihpalestina.com. Bantuan yang diberikan juga bermacam-macam, namun donasi dalam bentuk uang merupakan bantuan yang paling umum (Hadiansyah, 2021; Sasongko, 2021). Gerakan dukungan terhadap warga Palestina juga dilakukan secara politis oleh dilakukan oleh tokohtokoh seperti Presiden Republik Indonesia, Joko Widodo, kepala daerah maupun politisi-politisi Dewan Perwakilan Rakyat-DPR (Erwanti, 2021; 
Nurdiansyah, 2021; Sadewo, 2021).

Media di Indonesia berperan dalam memberitakan konflik Israel-Palestina seiring warga yang melakukan pergerakan sosial. Para peneliti mengatakan bahwa bahwa pesan media berpengaruh secara signifikan terhadap geopolitik dan pemahaman masyarakat terhadap kekuatan global (Ramasubramanian \& Miles, 2018). Media menempati posisi yang strategis diantara publik dan pemerintah sehingga berfungsi sebagai representasi publik terhadap pemerintah dan juga sebaliknya. Namun, media juga bisa menjadi aktor yang menentukan sendiri agendanya (McNair, 2011). Pemberitaan media di sebuah negara juga bisa menjelaskan hubungan negara tersebut dengan negara lainnya (Fong \& Ponnan, 2019).

Hubungan bilateral antara Indonesia dengan Palestina maupun hubungan Indonesia-Israel berlangsung sepanjang sejarah negara Indonesia. Indonesia mengakui Palestina sebagai negara berdaulatdanmembangun kerjasamabilateral dengan menempatkan perwakilan negara (duta besar) untuk Palestina dan juga sebaliknya. Sementara Indonesia tidak memiliki hubungan diplomatik dengan Israel. Hubungan bilateral antara Pemerintah Indonesia dan Palestina merepresentasikan dukungan masyarakat Indonesia terhadap Palestina. Meski begitu, terdapat juga masyarakat Indonesia yang menganut aliran judaisme yang berasal dari Israel (Lestari, 2018) dan mendukung Negara Israel (Margianto, 2010).

Masyarakat Indonesia mengikuti perkembangan konflik Palestina-Israel melalui berbagai media. Perkembangan media global maupun media di Indonesia memberikan akses terhadap sumber informasi yang beragam sehingga informasi menjadi berlimpah. Di tengah berbagai pilihan sumber berita, Lembaga Survey Indonesia (LSI) mengatakan media televisi masih merupakan sumber utama informasi politik di masyarakat Indonesia (Yangyue, 2014). Meski begitu, siber news media berkembang cepat dalam beberapa tahun terakhir untuk menjadi salah satu sumber informasi politik utama bagi masyarakat. Dewan Pers Indonesia mendokumentasikan terdapat sekitar 43.400 siber news media di Indonesia membuat publik mempunyai keluasan dalam memilih informasi yang dibutuhkan (Setiawan, 2020). Siber news media menjadi referensi informasi publik seiring kredibilitasnya yang meningkat di mata masyarakat karena memiliki berbagai keunggulan seperti kecepatan, akurasi dan objektifitas (Margianto and Syaefullah, 2012).

Para peneliti mempunyai pandangan berbeda mengenai perkembangan media siber di Indonesia. Sebagian peneliti melihat bahwa media siber memberikan peluang terbukanya demokrasi media yang lebih baik karena media jenis ini bisa dikuasai warga masyarakat dengan modal yang jauh lebih sedikit dibanding media televisi maupun media cetak (Saefullah and Margianto, 2012), sementara peneliti lain menganggap perkembangan media siber cenderung dipengaruhi oleh kapital ekonomi (Tapsell, 2015), dan politik (Djuyandi et al., 2017). Faktor ekonomi dan politik secara langsung maupun tidak langsung mempengaruhi objektifitas media dalam melaporkan sebuah peristiwa (Kperogi, 2013).

Peristiwa konflik Israel-Palestina telah menarik perhatian peneliti di seluruh dunia termasuk peneliti asal Indonesia karena konflik ini merupakan salah satu tragedi kemanusiaan terbesar di dunia dan telah berlangsung sejak awal abad 20 (Dwiastuti, 2021). $\mathrm{Wu}$ et al. (2002), menemukan media barat dan media berbahasa arab melakukan bingkai berbeda terhadap konflik Israel-Palestina (Wu et al., 2002). Sementara itu Shadiqi et al. (2020) menyebutkan bahwa dukungan warga Indonesia terhadap Palestina ditunjukkan melalui petisi elektronik. Menurut mereka, petisi-petisi tersebut didorong oleh simpati warga terhadap kekerasan, dukungan terhadap kemerdekaan Palestina, solidaritas, kebencian dan emosi negatif, dan identitas relijius (Shadiqi et al., 2020).

Sebagai salah satu negara dengan populasi terbesar dunia, Indonesia menempati posisi penting dalam politik global. Indonesia menjadi anggota Persatuan Bangsa-Bangsa (PBB) sejak 28 September 1959 dan berperan sebagai anggota tidak tetap Dewan keamanan PBB yang keempat kali di periode 2019-2020. Menurut Fong and Ponnan (2019) pemberitaan media di sebuah negara bisa menjelaskan hubungan bilateral antara negara tersebut dengan negara lainnya. Namun objektifitas media dalam memberitakan konflik Palestina-Israel perlu mendapatkan perhatian lebih lanjut khususnya dalam konteks media di Indonesia. Tujuan penelitian ini adalah untukmenganalisa objektifitas pemberitaan media siber di Indonesia mengenai konflik IsraelPalestina. Studi ini mengadopsi konsep objektifitas jurnalisme dengan data didapatkan dari tiga media siber nasional Indonesia. Studi ini menginvestigasi pemberitaan Okezone.com, Kompas.com dan Detik. com sebagai obyek penelitian karena ketiga media siber tersebut merupakan situs berita yang paling banyak diakses pada saat penelitian berlangsung menurut analisa alexa.com. Karenanya pertanyaan penelitian studi ini adalah bagaimana objektifitas tiga media siber di Indonesia dalam memberitakan konflik Israel-Palestina?

\section{Memahami Objektifitas Media Siber}

Objektifitas pemberitaan identik dengan kebebasan berbicara yang berlaku dalam negara demokrasi versi "barat" (Westerståhl, 1983). Riset 
Westersthal (1983) menjadi salah satu rujukan dalam menganalisa media dan perkembangannya. McQuail (2010) mengatakan bahwa objektifitas merupakan konsep utama dari informasi yang berkualitas. Objektifitas menurut McQuail adalah praktik media yang khusus dan perilaku jurnalis dalam memproses dan menyebarkan kembali informasi. McQuail menambahkan bahwa objektifitas media memiliki arti yang kompleks. Namun, ia mencoba menyederhanakan pengertian objektifitas media sebagai sesuatu yang lahir dari berita terpercaya mengenai apa yang terjadi di dunia. Menurut Mothes (2017), objektifitas media merupakan konsensus antara jurnalis dan warga mengenai informasi terhadap sebuah peristiwa. Objektifitas media adalah sesuatu yang normatif yang bergantung pada pemahaman jurnalis dan warga mengenai wacana publik seharusnya berjalan dalam lingkungan yang demokratis (Mothes, 2017).

Objektifitas bisa diartikan berbeda oleh awak media karena tekanan pemilik, perkembangan sosial politik (Adeyemo, 2020) dan faktor individu jurnalis (Mothes, 2017). Objektifitas juga merupakan hal yang dinamis sehingga bisa berubah seiring waktu (Carlson, 2019). Konsep objektifitas jurnalisme juga mendapat kritik karena secara mekanis menempatkan dua pihak berlawanan terjuktaposisi (Kperogi, 2013).

Dua dimensi yang menjadi fokus dalam objektifitas media adalah faktualitas dan imparsialitas (Westersthal, 1983; McQuail, 2010). Faktualitas artinya media memberikan informasi berdasarkan fakta apa, siapa, kapan, dimana, kenapa (who, what, when, where, why-5W). Namun, pemahaman terhadap faktualitas bisa berbeda dari waktu ke waktu yang membuat norma kesepakatan tersebut terkoreksi. Menurut Anggoro (2012), media siber mengembangkan informasi berdasarkan apa, kapan, dimana (what, when, where - 3W) dan bukan 5W. Penerapan $3 \mathrm{~W}$ merupakan negosiasi dari budaya media siber yang mengejar kecepatan. Namun, konsep 3W ini bukanlah hal baru karena sudah dikenal sejak abad 19 (Anggoro, 2012). Faktualitas juga bisa diartikan sebagai memiliki relevansi dan informatif. Imparsialitas maksudnya adalah bahwa pemahaman media atau jurnalis tidakmempengaruhi pemilihan dan interpretasi akan sebuah informasi dalam memahami sebuah topik (Mothes, 2017). Imparsial bisa diartikan sebagai sikap netral yang harus didapatkan melalui berbagai kombinasi keseimbangan (setara atau proporsional baik waktu/ruang/penekanan) yang berlawanan dengan interpretasi dan pandangan pada sebuah peristiwa (McQuail, 2010).

Perkembangan media siber dalam produksi dan diseminasi berita sangat dipengaruhi oleh motivasi ekonomi dan secara praktik dipengaruhi oleh mesin pencari Google (Prawira \& Rizkiansyah, 2018). Media mendapatkan informasi dan memilih berita yang akan disampaikan kepada publik berdasarkan hasil analisis data algoritma. Senada dengan hal tersebut, Carlson (2019) mengatakan bahwa pengaruh algoritma mesin pencari membuat objektifitas komputasional berpengaruh lebih besar dibanding subjektifitas jurnalis.

Adeyemo (2020) menyarikan pemikiran McQuail (2010) untuk menjelaskan objektifitas journalismemenjadi tiga hal yaitu; objektifitas terhadap ekspektasi public, objektifitas media terhadap opini professional, dan objektifitas media mendasarkan pada etika jurnalistik. Objektifitas media berdasarkan ekspektasi publik adalah pemberitaan yang dilakukan mengikuti pendapat publik secara umum tanpa mengurangi, menambahkan atau mewarnai sebuah fakta (Adeyemo, 2020). Studi ini memahami pendapat perwakilan pemerintah di negara demokrasi mengenai politik sebagai perwakilan masyarakat secara umum. Pemerintah yang lahir dari proses demokrasi dianggap sebagai perwakilan mayoritas masyarakat meski terdapat anggota masyarakat yang tidak setuju dengan pendapat pemerintah. Meski begitu, kami berargumen bahwa penentuan berita kini tidak dimonopoli oleh elit politik seperti pemerintah melainkan terdapat kontribusi warga melalui informasi yang mereka bagi melalui media sosial.

Objektifitas media berdasarkan opini profesional maksudnya adalah laporan yang disampaikan oleh seorang jurnalis dibatasi oleh fungsinya untuk menginformasikan, menghibur dan mengedukasi publik. Media memiliki fungsi yang sudah ditetapkan dalam undang-undang Pers No.40/99 yaitu sebagai media informasi, media edukasi, media hiburan, dan media pengawas pemerintahan. Undang-undang Pers membebaskan media di Indonesia untuk menjalankan fungsinya setelah sebelumnya terbelenggu pada era orde baru. Meski bebas, Tapsell (2015) berargumen bahwa media Indonesia cenderung dipengaruhi oleh motivasi ekonomi. Pada bisnis media siber, motif ekonomi diterjemahkan menjadi motif untuk mencapai jumlah pembaca yang tinggi (pageviews) sehingga memprioritaskan unsur hiburan. Dimesi hiburan dalam berita diindikasikan dari variabelvariabel seperti komentar selebritis, cerita fiksi/ dongeng, ataupun kejadian lucu. Sementara itu perbedaan dimensi edukasi dan informasi terletak pada tujuan yang ingin diraih penulis. Pada dasarnya berita bertujuan mengkonstruksi realitas yang tengah terjadi atau informatif. Namun jika informasi yang disampaikan bersifat mendidik maka informasi tersebut edukatif. Contoh edukatif adalah sejarah kemerdekaan RI.

Objektifitas media berdasarkan etika jurnalistik 
artinya adalah kerja jurnalistik seyogyanya berdasarkan moral dan prinsip mengenai benar dan salah yang telah disepakati bersama. McQuail dan Windahl (2015) mengatakan bahwa etika jurnalistik hanyalah panduan perilaku atau praktis yang berupa prinsip sehingga aturan tersebut mempunyai kekuatan hukum (McQuail \& Windahl, 2015). Namun, etika jurnalistik merupakan salah satu pembeda antara jurnalis dengan non-jurnalis. Dalam konteks Indonesia, perbedaan keduanya menyangkut perlindungan hukum jika terdapat sengketa dalam pemberitaan.

Adeyemo (2020) mengatakan bahwa jurnalis cukup melakukan pekerjaannya pada ketiga ranah tersebut dan kegiatan apapun yang melebihi ranah tersebut bisa disebut sebagai aktivisme. Ketiga fungsi professional media di atas telah dipahami secara global namun, McQuail dan Windahl (2015) menyebut bahwa fungsi media juga membuatnya kerap berlawanan dengan pemerintah. Objektifitas media yang mendasarkan pada etikajurnalistik adalah memberitakan fakta (kebenaran, informatif, relevan) dan imparsialitas (berimbang, netral). Konsep objektifitas jurnalisme merupakan perlawanan terhadap sifat alami jurnalisme yang memberikan perlakuan istimewa kepada kelas dominan dalam masyarakat (Kperogi, 2013). Studi ini menggunakan definisi objektifitas peliputan Adeyemo (2020) karena dianggap lebih cocok dalam menganalisa objektifitas media saat melaporkan konflik IsraelPalestina.

\section{Perkembangan Media Siber Indonesia}

Kualitas jurnalisme di Indonesia mengalami masa naik dan turun mengikuti perkembangan politik nasional. Di masa kemerdekaan tahun 1945, media Indonesia optimis menjadi corong bagi suara rakyat. Namun, sejak tahun 1965 media di Indonesia berada dalam kondisi tertekan karena pemerintah yang otoriter. Optimisme akan kualitas jurnalisme yang baik muncul setelah masa reformasi di tahun 1998. Di masa reformasi, media mendapat perlindungan Undang-undang Pers No. 40/1999 dalam menjalankan fungsinya. Namun, dua dekade setelah reformasi, media di Indonesia semakin dipengaruhi oleh kapital ekonomi yang artinya media menjalankan praktik jurnalisme didominasi oleh kepentingan untuk mendapatkan keuntungan ekonomi (Prawira, 2019; Tapsell, 2012). Media di Indonesia menerapkan berbagai praktik mendasarkan pada motivasi ekonomi, diantaranya; praktik pengaplikasian search engine optimisationSEO (Eddyono, 2020), praktik native advertising (Pasandaran \& Mutmainnah, 2020), komodifikasi dan pemanfaan media social (Muslikhin et al., 2021). Media menerapkan keberimbangan semu ketika memberitakan perhelatan politik seperti pemilihan kepala daerah. Keberimbangan berita terhadap kandidat kepala daerah dilakukan karena para kandidat merupakan pasar native advertising atau advertorial bagi perusahaan media (Prawira, 2019).

Media di Indonesia secara aktif menentukan sendiri agenda setting media atau menjadi partisan partai politik tertentu (Djuyandi et al., 2017). Dalam perhelatan politik pemilihan presiden RI tahun 2014 media partisan mendukung kandidat yang terafiliasi dengan perusahaan media. Hal ini senada dengan apa yang disampaikan Tapsell (2015) bahwa media partisan di Indonesia secara aktif melakukan kampanye dengan menampilkan keunggulan kandidat yang didukungnya untuk mempengaruhi preferensi publik dalam pemilu. Jurnalisme partisan dikenal sebagai kerja jurnalistik yang membela pihak tertentu. Partisan media diidentifikasi melalui praktik media dalam melakukan pembingkaian berita yang menguntungkan satu pihak tertentu melalui frekwensi berita, nada berita, dan pemilihan isu berita. Fenomena media partisan menguatkan pendapat bahwa media tidak hanya berlaku sebagai medium informasi publik dan pemerintah tapi juga berperan sebagai aktor politik di masyarakat (Butsch, 2007; Swanson, 2005).

Dominasi motivasi politik atau ekonomi menjadi indikator buruknya kualitas jurnalisme. Sebaliknya jurnalisme berkualitas identik dengan jurnalisme yang memprioritaskan kapital kultural. Bourdieu (2005) menyebut jurnalisme berkualitas yang disebutnya sebagai jurnalisme serius harus otonom dan terbebas dari tekanan politik maupun ekonomi (Bourdieu, 2005). Jurnalisme berkualitas dapat berupa jurnalisme investigasi atau tipe-tipe karya jurnalisme yang mendapatkan penghargaan seperti Pulitzer. Jurnalis Indonesia mengenal jurnalisme berkualitas sebagai jurnalisme kontekstual (Prawira, 2019). Kualitas jurnalisme kontemporer Indonesia telah menarik perhatian peneliti-peneliti seperti Ambardi et al. (2018) yang mengungkap bahwa perkembangan digital menyebabkan kualitas jurnalisme yang menurun (Ambardi et al., 2018). Praktik search engine optimisation (SEO) atau pemanfaatan Google dalam produksi dan diseminasi media online membuat kualitas jurnalisme menurun dan merusak keragaman informasi (Eddyono, 2020). Pratiwi dan Ambardi (2020) menyelidiki kecenderungan media siber dalam memberitakan berita politik dengan berita hiburan yang juga membuat kualitas jurnalisme menurun. Di sisi lain riset objektifitas media di Indonesia masih jarang dilakukan. Riset objetivifitas dilakukan oleh Fisilla (2021) untuk menganalisa teks berita "Pikiran Rakyat"yang diterjemahkan ke dalam bahasa Inggris. Mereka menemukan bahwa terdapat bias dalam versi 
bahasa Inggris yang disebabkan oleh objektifitas penerjemah. Riset Fisilla dan Syihabuddin fokus terhadap pemahaman penerjemah terhadap teks, sementara studi ini fokus pada objektifitas media dalam intepretasi peristiwa berdasarkan fakta dan imparsialitas (Fisilla, 2021).

Kualitas media dinilai atas kegunaan informasi yang disampaikan dalam meningkatkan kualitas hidup audiens (McQuail, 2010). Terkait hal tersebut media juga memiliki tanggung jawab sosial kepada masyarakat. Tanggung jawabnya sebagai pengawas kekuasaan dalam konteks negara demokrasi membuat media membangun hubungan adversarial dengan pemerintah (McQuail, 2015). Hubungan adversarial muncul karena media kerap mengkritisi pemerintah untuk menjalankan fungsinya sebagai anjing penjaga (wathcdog). Namun fungsi ini tergerus karena media menerima iklan politik pemerintah (Ghazali, 2011). Peneliti media berpendapat fungsi media sebagai ruang publik telah hilang karena lebih melayani pemerintah dan mencari keuntungan ekonomi (Butsch, 2007). Media juga menerima iklan politik kandidat kepala daerah (Ghazali, 2011) sehingga berita mengenai kandidat kepala daerah selalu bernada (tone) positif dan berimbang (Prawira, 2019). Keberimbangan pemberitaan untuk menutupi perbedaan perhatian media karena motivasi ekonomi atau politik dikenal dengan keberimbangan semu atau false balance (Rietdijk \& Archer, 2021; Robin, 2014).

Penelitian kualitas media juga fokus pada jenis media yang ada di masyarakat. Konsep media mainstream seperti media cetak mendapat predikat sebagai media yang paling berkualitas dibanding media televisi dan lainnya (Yangyue, 2014). Masyarakat juga mendapatkan informasi dari social media yang dikenal juga sebagai media alternatif(Fuchs \& Sandoval, 2015). Namun, konsep biner antara media arus utama dan media alternatif memberikan permasalahan. Misal Menurut Rauch (2016) perbedaan antara keduanya telah semakin kabur. Kperogi (2013) juga mengatakan bahwa media arus utama dan media alternatif melakukan praktik jurnalistik yang sama. Serupa dengan Kperogi, Nygaard (2019) mengatakan bahwa keduanya memiliki tampilan yang sama (Nygaard, 2019). Meski begitu, dikotomi media arus utama dan media alternatif merupakan masalah hegemoni dan power. Menurut Rauch (2016) perbedaaan antara media arus utama dan media alternatif tidak begitu jelas dalam negara demokrasi liberal dibandingkan negara authoritarian (Rauch, 2016). Dalam konteks Indonesia, garis tegas perbedaan keduanya secara aktif dibangun oleh jurnalis dan Dewan Pers Indonesia. Jurnalis Indonesia bersaing dengan non-jurnalis untuk menjadi aktor yang dapat mempengaruhi opini publik (Prawira \& Irawan, 2020). Dewan pers Indonesia menentukan pihak mana yang layak menyandang status sebagai pers melalui verifikasi media.

Pengakuan media oleh Dewan Pers tidak hanya sebatas legitimasi saja tapi juga menyangkut status hukum media. Indonesia mempunyai perundangan yang mengatur kegiatan jurnalistik secara berbeda. Yang pertama adalah undang-undang pers yang menjamin kebebasan pers. Pers yang "diakui" akan mendapatkan perlindungan dan mendapatkan mediasi dewan pers jika terjadi sengketa pers. Sementara pers yang "tidak diakui" akan terancam undang-undang Informasi dan Transaksi Elektronik (ITE) seperti yang dialami citizen jurnalis yang akhirnya harus dipenjara karena tuduhan pencemaran nama baik. Dikotomi media mainstream dan alternatif juga berlaku untuk memberikan status bagi citizen jurnalis sebagai bukan jurnalis.

Perkembangan peraturan perundangan Indonesia mempengaruhi media baru seperti media online. Media ini memiliki karakter lebih interaktif dibanding media lainnya sehingga bisa mengadaptasi jurnalis warga lebih mudah. Dengan jurnalisme warga, publik mendapatkan peluang untuk ikut serta dalam produksi dan diseminasi berita yang selama ini dimonopoli oleh media mainstream. Namun, belakangan karakter interaktif tersebut juga mudah terpapar berita bohong atau fake news sehingga mempengaruhi kualitas jurnalistik. Jurnalis media online kemudian menyepakati aturan Pedoman Penulisan Berita Siber untuk menjaga kualitas konten dan praktik jurnalisme siber.

Media siber kini menempati posisi penting di masyarakat dan di pemerintahan Indonesia. Berdasarkan ranking alexa.com media siber, menjadi situs yang paling banyak dikunjungi selain situs mesin pencari. Sebelumnya media siber dikenal sebagai alternative media dari media mainstream seperti koran, radio dan televisi. Jurnalis media ini mengembangkan metode yang berbeda dalam produksi dan diseminasi berita dibanding media arus utama sebelumnya. Media siber mengembangkan bentuk berita yang kompak dibanding berita tradisional traditional (Anggoro, 2012). Namun metode ini berimplikasi pada kualitas berita siber dan membuat media siber dikenal dengan jurnalisme berkualitas rendah. Meski begitu, media siber tetap mendapatkan kepercayaan publik seiring waktu. Beberapa perusahaan media mengembangkan berita siber yang berkualitas atau dikenal dengan berita kontekstual.

Keunggulan media siber lainnya adalah mudah berkolaborasi dengan platform lain. Peluang ini juga dilihat oleh media-media lama seperti radio dan televisi yang berkonvergensi dengan 
media siber. Strategi konvergensi juga membuat media-media mainstream menguasai sosial media. Media arus utama menempati posisi paling banyak pengikut membuat perusahan media berpeluang besar menguasai wacana publik dengan menguasai konten di media sosial. Seperti yang diungkap Muslikhin et al. (2021) bahwa media yang paling banyak dikunjungi di Indonesia, tribunews.com memiliki tim khusus untuk mengelola social media. Mereka menemukan bahwa media sosial digunakan perusahaan media untuk mendatangkan keuntungan ekonomi.

\section{Berita dan Kebijakan Luar Negeri Indonesia}

Kerja jurnalistik Indonesia diatur oleh ragam peraturan dan perundangan. Setahun setelah masa reformasi, kerja jurnalistik dilindungi oleh UU Pers No 49/1999. Sebelum masa ini, pers Indonesia diatur oleh authoritarian rezim (Phillpot, 2000) yang membelenggu pers melalui Surat Ijin Usaha Penerbitan dan Percetakan (SIUPP), budaya telepon dan breidel (Ghazali, 2004; Margiyono, 2009; Sen \& Hill, 2007). Selain peraturan perundangan, media di Indonesia menyepakati kode etik jurnalistik yang sejalan dengan kode etik jurnalistik global. Media televisi dan radio memiliki aturan khusus yang diatur oleh Pedoman Perilaku Penyiaran dan Standar Program Siaran (P3SPS), sementara media siber sebagai media arus utama termuda diatur oleh Pedoman Penulisan Berita Siber. Baik kode etik maupun perundangan mengatur berbagai hal praktis pelaksanaan kerja jurnalistik panduan penggunaan kamera terselubung, penayangan iklan, hingga peliputan konflik. Berdasarkan aturan yang disepakati, media diharuskan bersikap netral dalam melaporkan konflik atau pertentangan antara dua pihak. Kode etik jurnalistik pasal 5 misalnya menyebut "Wartawan indonesia menyajikan berita secara berimbang dan adil" (Dewan Pers Indonesia, N.D).

Pada prakteknya, jurnalis memberitakan peristiwa atau informasi berdasarkan seperangkat pemahaman nilai berita. Harcup dan O'neill merangkum nilai berita tersebut dalam sepuluh poin (lihatHarcupdanO'neill,2001)diantaranya;kekuatan elit, hiburan dan berita buruk. Scholars terus menerus mengkaji dan merevisi pemahaman nilai berita ini sesuai dengan perkembangan jurnalisme masa kini. Seperti yang dilakukan Trilling et al. (2016) yang menyoroti perkembangan jurnalisme sehubungan dengan media sosial. Mereka menemukan bahwa salah satu nilai berita adalah kelayakannya untuk dibagikan atau shareworthiness (Trilling et al., 2017). Menurut mereka jurnalis tidak lagi menjadi satusatunya pihak yang menentukan berita mana yang akan disampaikan kepada publik. Namun, berita juga ditentukan oleh warga masyarakat melalui informasi yang disebarkan melalui media sosial. Pemahaman yang sama juga menjadi perhatian Prawira dan Rizkiansyah (2018), yang menemukan bahwa nilai berita di ruang berita ditentukan oleh publik melalui situs pencarian Google. Menurut mereka, jurnalis menentukan topik berita berdasarkan kata kunci yang paling banyak dicari publik melalui Google atau dikenal dengan metode SEO- search engine optimisation (optimalisasi mesin pencari).

Pemahaman nilai berita terus berkembang. Namun, pemahaman berita secara tradisional tetap bertahan, misalnya nilai berita berdasarkan negatifitas atau yang dikenal dengan istilah berita buruk adalah berita baik (bad news is a good news). Berdasarkan hasil penelitian eksperimen Trussler dan Soroka, pembaca secara alamiah merespon pada kata-kata negatif seperti kanker, bom, atau perang. Perhatian pembaca akan terhadap kata-kata negatif akan lebih cepat dibanding perhatian terhadap kata-kata positif seperti "senyum" dan "menyenangkan". Karena itulah kata-kata negatif lebih banyak menghiasi tajuk utama media (Trussler \& Soroka, 2014).

Kata negatif perang menghiasi tajuk utama media di berbagai belahan dunia pada awal bulan Mei 2021 ketika konflik Israel-Palestina kembali terjadi. Presiden Republik Indonesia (RI) Joko Widodo menyatakan melalui akun Twitter $10 \mathrm{Mei}$ 2021 bahwa ia mengutuk tindakan Israel yang menyerang warga sipil di Sheikh Jarrah Yerussalem Timur dan menyerang warga di mesjid Al-Aqsa. Pernyataan itu juga diperkuat oleh pidato Menteri Luar Negeri RI Retno Marsudi pada 20 Mei 2021 di pertemuan majelis Persatuan Bangsa-BangsaPBB (CNN Indonesia, 2021). Retno menguatkan pernyataan Presiden RI mengenai pandangan Indonesia pada konflik Israel-Palestina. Terdapat tiga hal yang menjadi perhatian utama Retno dalam pidatonya yaitu; pertama, Indonesia meminta Israel untuk menghentikan kekerasan dan agresi militer. Retno mendorong bahwa gencatan senjata bahwa agar peristiwa serupa tak terjadi di masa mendatang. Kedua, memastikan akses terhadap kemanusiaan dan melindung warga sipil. Ketiga, Indonesia mendorong negosiasi multilateral guna terciptanya perdamaian. Indonesia meminta Israel untuk menghentikan ketidakadilan terhadap warga Palestina dan mendukung kemerdekaan Palestina.

Pernyataan pemerintah RI yang mendukung rakyat Palestina menggambarkan hubungan bilateral Indonesia-Palestina. Kedua negara memiliki kesamaan penduduk dengan mayoritas muslim dengan komposisi $87.2 \%$ persen beragama Islam sementara sisanya Protestan, Katolik, Hindu, Budha dan Konghucu (Indonesia.go.id, n.d.). Meski begitu hukum Islam tidak diterapkan di negara berpenduduk 270,20 jutajiwa ini. Para founding fathers memutuskan 
demokrasi menjadi bentuk pemerintahan sejak Indonesia merdeka.

Pemberitaan media bisa menjelaskan identitas politik sebuah hubungan bilateral antar negara bisa dianalisa dari pemberitaan media setempat mengenai suatu isu. seperti yang dilakukan oleh Fong dan Ponnan (2019) yang meneliti hubungan bilateral Malaysia-China dalam pemberitaan hilangnya pesawat MH 370. Meskiterdapat perbedaan pendapat di masyarakat mengenai insiden pesawat tersebut, namun media kedua negara memberitakan hal positif mengenai hubungan Malaysia-China. Sementara itu, berita mengenai konflik Israel-Palestina telah lama menghiasi tajuk utama di Indonesia. Terdapat berbagai versi berita di Indonesia mengenai konflik Israel-Palestina. Namun, perkembangan media sosial telah memberikan tekanan kepada media arus utama dalammenentukan agenda baik secara positifmaupun negatif. Informasi di sosial media memberikan akses kepada publik untuk menyampaikan pendapat, meski kemudian pendapatnya tersebut berimplikasi hukum. Misalnya yang dialami siswi SMA di Bengkulu yang dikeluarkan pihak sekolah karena dianggap menghina Palestina melalui unggahan di Tik Tok (Kumparan, 2021), dan empat orang lainnya yang harus dipenjara karena tuduhan serupa (Prabawati, 2021).

Selain anggota masyarakat, perilaku media dan jurnalis dipengaruhi objektifitas individual mereka. Robinson dan Culver (2016) mengungkap bahwa jurnalis kulit putih tidak memberitakan cerita sebenarnya mengenai kasus rasisme di Madison, Amerika Serikat. Jurnalis kulit putih menggunakan perspektif berdasarkan latar belakangnya tersebut dan menganggap pihak lainnya, baik itu pihak asing atau minoritas lebih rendah. Shadiqi et al. (2020) mengatakan bahwa solidaritas masyarakat Indonesia didorong oleh indentitas persaudaraan yang memahami penindasan warga Palestina. Mayoritas penduduk Indonesia adalah muslim sehingga menurut Shadiqi et al. (2020) membuat gerakan relijius-politik untuk mendukung Palestina salah satunya melalui petisi elektronik dalam mendukung kemerdekaan Palestina.

\section{METODE}

Penelitian ini merupakan penelitian kuantitatif dengan metode analisis konten mengadopsi konsep objektifitas jurnalisme. Data penelitian didapatkan dari berita yang dipublikasi tiga media siber nasional Indonesia selama bulan Mei-Juni 2021. Studi ini mengumpulkan 675 berita atau rata-rata 25 berita per hari yang telah terpublikasi di tiga media sibernasional Indonesia. Kami melakukan pencarian dengan kata kunci Palestina dan Israel pada internal search tool.
Penentuan Okezone.com, Kompas.com dan Detik. com sebagai obyek penelitian karena ketiga media siber tersebut merupakan situs berita yang paling banyak diakses pada saat penelitian berlangsung menurut analisa alexa.com. Data didapatkan dari rekaman layar (screen shot) setiap berita mengenai Palestina maupun Israel dan menyimpannya pada Google Drive. Dengan mengikuti Slovin (Yusuf, 2016) didapatkan sampel secara acak menggunakan Microsoft Excel dengan jumlah 225 berita. Kami mengembangkan definisi operasional bagi setiap variabel objektifitas media dan mengujinya. Sebelum berita dianalisis kami melakukan tes intercoder reability terhadap 10 persen total berita (Neuendorf, 2016) yaitu 25 sampel berita. Kami menganalisa konten dengan univariat analysis (Bryman, 2012) mengikuti objektifitas media sebagai kategori utama yaitu; objektifitas berdasarkan harapan publik, objektifitas berdasarkan opini profesional, objektifitas berdasarkan etika jurnalistik.ini berisi metode yang digunakan dalam penelitian, apa atau siapa saja sumber datanya, bagaimana sumber data itu diperoleh (cara menentukan sumber data) dan kemudian bagaimana data itu divalidasi.

\section{HASIL DAN PEMBAHASAN}

Media siber Indonesia menjadikan peristiwa konflik Israel-Palestina sebagai peristiwa utama pada Mei 2021 meski pada saat yang sama Indonesia tengah menghadapi pandemi COVID-19. Kami meneliti tiga media berita dengan ranking tertinggi di Indonesia dengan okezone.com memproduksi berita terbanyak mengenai konflik Israel-Palestina diikuti detik.com dan kompas.com masing-masing 252 berita, 248 berita dan 176 berita. Uji intercoder reability (Bryman, 2012; Hayes \& Krippendorff, 2007) dilakukan sebelum analisis konten. Data hasil intercoder reliability menunjukkan persamaan persepsi antar coder mendekati 100 persen. Kami menguji tiga reliabilitas yaitu objektifitas berdasarkan harapan publik, objektifitas berdasarkan opini profesional, objektifitas berdasarkan etika jurnalistik. Nilai intercoder reliability tertinggi terjadi pada variable pada opini profesional dengan nilai 0.9 of Cronbach's alpha. sementara nilai terkecil intercoder reliability didapatkan dari objektifitas berdasarkan etika jurnalistik. Rata-rata intercoder reliablity adalah 0.875 Nilai tersebut termasuk dalam 'satisfactory level'(Bryman, 2016). Kami mengkategorisasi objektifitas berdasarkan harapan publik melalui narasumber yang diakomodasi dalam berita yang dipublikasi. kategoriobjektifitas berdasarkan harapan publik adalah publik dan komunitas, politisi, pemerintah, dan media. Kategori objektifitas berdasarkan opini profesional didasarkan pada opini berita, hiburan dan pendidikan. Sementara kategori objektifitas berdasarkan etika 
jurnalistik fokus pada keberimbangan, dan akurasi berita.

\section{Objektifitas Berdasarkan Harapan Publik}

Pada analisis objektifitas media terhadap ekspektasi publik kami melakukan konfirmasi berita berdasarkan dukungan masyarakat Indonesia terhadap Palestina berdasarkan kebijakan politik Presiden RI dan Menteri Luar Negeri RI, Retno Marsudi pada rapat dewan keamanan PBB pada 20 Mei 2021. Kami juga melakukan investigasi terhadap dokumen trending topic Twitter mengenai kecenderungan dukungan publik di media sosial. Dukungan publik pada isu tertentu bisa terlihat juga dari narasumber yang dikutip oleh media apakah masyarakat biasa. Seperti yang ditunjukkan tabel 1, jumlah berita yang didasarkan dari informasi masyarakat hampir sama dengan jumlah berita yang berdasar dari informasi pemerintah. Informasi dari pemerintah tidak hanya bersumber dari pemerintah pusat RI tapi juga dari aparatur negara lain seperti pemerintah daerah, polisi, ataupun pemerintah negara asing.

Tabel 1. Objektifitas Media berdasarkan Ekspektasi Publik

\begin{tabular}{lcccc}
\hline & Publik & Pemerintah & Politisi & Media \\
\hline Okezone.com & 34 & 24 & 5 & 27 \\
Kompas.com & 14 & 21 & 4 & 13 \\
Detik.com & 25 & 20 & 10 & 28 \\
\hline \multicolumn{1}{c}{ Total } & 73 & 65 & 19 & 68 \\
\hline
\end{tabular}

Hasil analisis objektifitas media dalam memberitakan konflik Israel-Palestina menunjukkan jumlah berita dengan narasumber publik, pemerintah dan media tidak berbeda secara signifikan. Sebanyak $32 \%$ berita yang menjadi sampel penelitian ini menunjukkan bahwa narasumber yang berasal dari masyarakat biasa atau dari organisasi masyarakat. Sementara sumber media adalah $30 \%$ dari total sampel yang diteliti. Pemerintah dan politikus masing-masing dan 9\% dan 29\% (lihat gambar 1).

Sumber berita yang berasal dari masyarakat

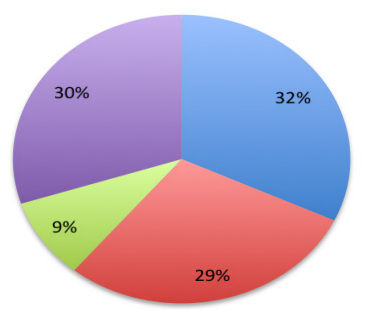

$$
\begin{aligned}
& \text { = Publik } \\
& \text { = Pemerintah } \\
& \text { = Politisi } \\
& \text { Media }
\end{aligned}
$$

Gambar 1. Objektifitas Media Berdasarkan Ekpektasi Publik

didominasi oleh berita pengumpulan dana oleh masyarakat untuk membantu warga palestina yang terdampak konflik. Organisasi masyarakat berbasis keagamaan seperti Nahdatul Ulama, dan
Muhamadiyah juga memenuhi pemberitaan karena menggalang dana atau bersumber dari pernyataan dukungan ormas-ormas tersebut terhadap Palestina. Sumber berita yang berasal dari media tidak mencatumkan narasumber yang pada umumnya merupakan gabungan informasi. Tipe berita seperti ini biasa digunakan media dalam editorial. Hal ini menunjukkan bahwa media secara aktif membangun agenda setting dalam mendukung Palestina. Seperti yang disampaikan MCNair (2011) bahwa media secara aktif menjadi aktor politik.

Sumber berita dari pemerintah berasal dari pernyataan Presiden RI dan Menlu RI pada awal konflik yang kemudian menjadi menjadi tajuk utama semua media di Indonesia. Meski begitu, tidak ada lagi pemberitaan yang kontinyu bersumber dari pemerintah RI yang dipublikasikan ketiga media. Selain pemerintah RI, sumber pemerintah lain seperti pemerintah Arab Saudi, pemerintah Amerika Serikat, ataupun pemerintah daerah DKI.

Peristiwa konflik Israel-Palestina juga menjadi perhatian politikus Indonesia. Media mengutip politikus yang mendukung kemerdekaan Palestina dan menyerukan gencatan senjata. Politikus diidentifikasi sebagai orang berlatar belakang partai politik baik menempati posisi di Dewan Perwakilan Rakyat (DPR) ataupun tidak.

Data penelitian menunjukkan tidak ada pihak yang memberi tekanan pada media dalam memberitakan konflik Israel-Palestina. Politisi menjadi yang paling jarang digunakan sebagai narasumber karena isu ini bukanlah isu politik nasional seperti halnya pemilu. Media berperan penuh secara mandiri dalam memberitakan konflik ini. Narasumber pemerintah dan publik mungkin juga amplifikasi agenda setting yang telah ditetapkan oleh media sebelumnya.

\section{Objektifitas Media Berdasarkan Opini Profesional}

Pada analisis objektifitas berdasarkan opini professional jurnalis kami mengidentifikasinya berdasarkan informasi, hiburan dan edukasi. Objektifitas profesional informasi mendominasi berita yang disampaikan media dengan detik. com menjadi media yang paling informatif seperti ditunjukkan tabel 2.

Tabel 2. Objektifitas Media Berdasarkan Opini Profesional

\begin{tabular}{lrrrr}
\hline & Informatif & \multicolumn{2}{c}{ Hiburan } & \multicolumn{2}{c}{ Edukatif } \\
\hline Okezone.com & 66 & 16 & 4 \\
Kompas.com & 48 & 4 & 5 \\
Detik.com & 71 & 6 & 5 \\
\hline 'Total & 185 & 26 & 14 \\
\hline
\end{tabular}

Secara akumulatif informasi menjadi konten 
media siber paling utama dengan presentase $82 \%$. Sementara hiburan dan edukasi masing-masing $12 \%$ dan $6 \%$ seperti ditunjukkan oleh gambar 2 . Berita yang menjadi sampel pada penelitian ini menceritakan agresi militer Israel terhadap Palestina, jumlah korban, dan informasi dukungan terhadap Palestina.

Media juga melihat sisi hiburan dari konflik

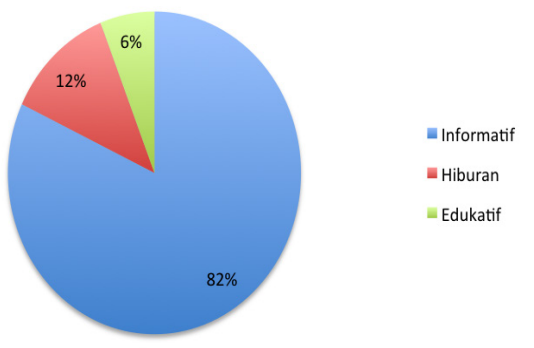

Gambar 2. Objektifitas Berdasarkan Opini Profesional

Israel-Palestina dengan menceritakan dukungandukungan selebritas nasional maupun internasional terhadap kemanusiaan maupun terhadap kedaulatan Palestina. Sementara opini profesional edukasi disampaikan melalui cerita sejarah dukungan Indonesia terhadap Palestina, sejarah konflik antara Israel Palestina, dan profil-profil pejuang Palestina.

Berita di media tidak menunjukkan hubungan adversarial antara media dengan pemerintah karena dua hal, yaitu; pertama, pemerintah minim mengangkat isu konflik Israel-Palestina. Pemerintah RI menunjukkan sensitivitasnya terhadap peristiwa yang terjadi di Palestina. Presiden RI dan pernyataan resmi Menteri Luar Negeri RI pada pertemuan majelis PBB. Namun, setelah itu relatif tak ada lagi berita mengenai konflik Israel-Palestina yang bersumber dari pemerintah RI. Kedua, media memiliki agenda yang sama dengan pemerintah pada isu ini. Sejatinya media menjalankan fungsi profesionalnya sebagai pengawas pemerintahan atau watchdog. Namun, media tidak menjalankan fungsi tersebut pada pemberitaan konflik Israel-Palestina. Media bisa memberikan kritik terhadap pemerintah misalnya kontinyuitas bantuan yang seharusnya diberikan pemerintah RI mengingat konflik IsraelPalestina bukanlah yang pertama terjadi. Media di Indonesia memiliki ketergantungan terhadap pemerintah sebagai pengiklan pada masa krisis ekonomi media dan krisis Covid19 (Prawira, 2020). Hubungan itu membuat media tidak kritis terhadap pemerintah, dan cenderung mendukung kebijakankebijakan yang dikeluarkan pemerintah.

\section{Objektifitas Media Berdasarkan Etika Jurnalistik}

Pada objektifitas berdasarkan etika jurnalistik, kami mengikuti petunjuk McQuail dengan membatasi analisa pada penulisan dua sisi dan tidak memihak. Terdapat negosiasi terhadap etika jurnalistik mengenai penulisan media siber(Anggoro, 2012). Narasi media siber yang singkat memiliki kecenderungan tidak menempatkan keberimbangan informasi pada satu berita yang sama. Sehingga, kami juga mencoba mengidentifikasi keberimbangan dari total keseluruhan berita yang diamati. Namun, hasil penelitian dan analisa sampel data menunjukkan $72 \%$ berita menceritakan tentang Palestina, sisanya $22 \%$ imparsial dan berita dari sudut pandang Israel sebanyak $6 \%$ dari total sampel berita yang kami teliti. menceritakan tentang upaya perdamaian kedua belah pihak. Data penelitian ini menunjukkan dukungan media di Indonesia terhadap Palestina sejalan dengan agenda publik, agenda masyarakat maupun agenda politisi. Temuan ini sejalan dengan penelitian Shadiqi et al. (2020) yang menyatakan bahwa warga Indonesia mendukung Palestina. Penelitian ini menemukan masyarakat Indonesia yang terdiri dari publik, pemerintah, politisi dan media sendiri mendukung Palestina.

Tabel 3. Imparsialitas Media dalam Berita Konflik Israel Palestina

\begin{tabular}{lccc}
\hline & Palestina & Israel & Neutral \\
\hline Okezone.com & 71 & 7 & 15 \\
Kompas.com & 54 & 3 & 22 \\
Detik.com & 38 & 3 & 12 \\
\hline
\end{tabular}

Berita yang menceritakan konflik dari sudut pandang Israel ditunjukkan melalui informasi deskripsi kekuatan militer Israel, dukungan Amerika Sertikat terhadap Israel, dan dukungan selebritas internasional seperti aktris Hollywood, Gal Gadot. Sementara berita imparsial ditunjukkan pada informasi upaya perdamaian yang dilakukan PBB.

Pada kategori akurasi seperti ditunjukkan

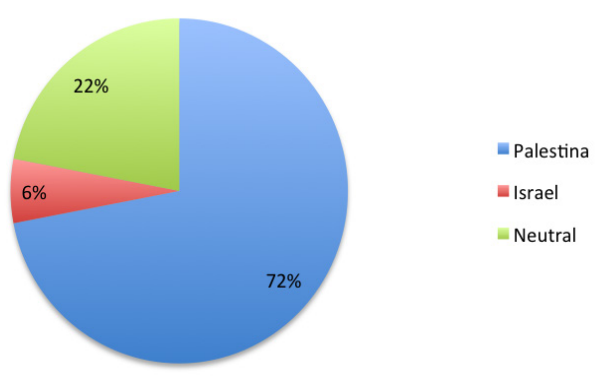

Gambar 3. Objektifitas media berdasarkan imparsialitas

oleh tabel 4, ketiga media telah menerapkan etika jurnalistik dengan baik dengan okezone. com menempati jumlah berita tertinggi. Media menampilkan data yang sesuai satu media dengan lainnya.

Hal ini mungkin dikarenakan ketiga media 
memiliki sumber informasi yang sama. Asumsi ini diperlihatkan dari absennya reporter lapangan saat konflik berlangsung sehingga ketiga media mengandalkan kantor berita, atau berita-berita yang telah tersebar di Internet.

Tabel 4. Akurasi Media dalam Berita Konflik IsraelPalestina

\begin{tabular}{ccc}
\hline & Akurat & Tidak akurat \\
Okezone.com & 80 & 12 \\
Kompas.com & 72 & 6 \\
Detik.com & 49 & 5 \\
\hline
\end{tabular}

Terdapat ketidaksesuaian judul dengan isi berita yang kami kategorikan sebagai click-bait namun jumlahnya tidak signifikan sehingga tidak terlihat dalam kompilasi data seperti terlihat pada gambar 4 .

Etika jurnalistik menuntut media melakukan

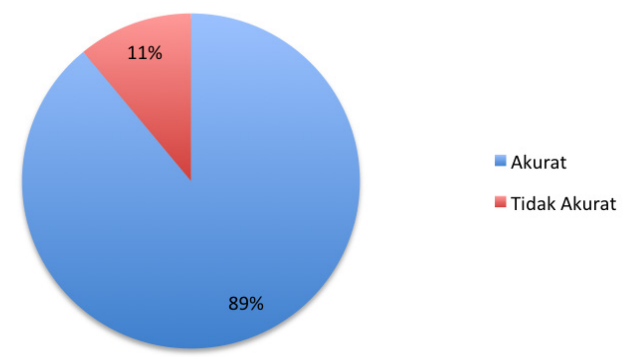

Gambar 4. Objektifitas Media Berdasarkan Akurasi

pemberitaan berimbang atas dua pihak yang bertikai. Namun, etika jurnalistik Indonesia juga menyebutkan bahwa media harus membela kepentingan publik. Meski hanya menceritakan konflik Israel-Palestina dari sudut pandang Palestina, media memenuhi tuntutan etis karena membela kepentingan masyarakat Indonesia. Hal ini sejalan dengan apa yang Shadiqi et al. (2020) temukan bahwa dukungan warga Indonesia terhadap Palestina dikarenakan kedekatan relijius muslim. Berita-berita yang menjadi sampel penelitian ini memperlihatkan dukungan terhadap Palestina dari kelompok warga muslim, pemuka agama Islam, dan selebriti-selebriti muslim.

Data penelitian menunjukkan bahwa media di Indonesia tidak menerapkan objektifitas profesional berdasarkan etika jurnalistik, namun lebih memilih mendukung kepentingan publik atau mayoritas warga. Seperti yang disampaikan Charles (2019) bahwa media tak bisa selalu obyektif dalam memberitakan sebuah peristiwa. Media menerapkan advocacy journalism untuk mendukung pihak tertentu baik politik maupun sosial (Charles, 2019).

Data penelitian ini menujukkan berita yang terpublikasi media menunjukkan motivasi dukungan terhadap Palestina. Meski begitu, terdapat warga masyarakat pro-Israel yang menunjukkan dukungannya melalui media sosial. Pernyataan pendukung Israel tersebut dikutip juga media siber namun tidak menjadi sampel dalam penelitian ini. Salah satu pendukung Israel Monique Rijkers berpendapat bahwa media di Indonesia tidak akurat dalam memberitakan peristiwa konflik IsraelPalestina. Menurutnya, pihak Israel tidak bersalah dalam konflik tersebut melainkan kesalahan kelompok militan Palestina, Hamas. Pemberitaan yang tidak akurat mengenai serbuan di Mesjid Al-Aqsa dan kebakaran di tembok Ratapan (Rijkers, 2020).

\section{SIMPULAN}

Hasil penelitian menunjukkan bahwa objektifitas media siber dalam memberitakan konflik IsraelPalestina mengikuti dukungan publik terhadap Negara Palestina. Media secara aktif mendukung Palestina dengan mempublikasi tulisan kompilasi. Media tidak fokus memanfaatkan narasumber dari pihak tertentu dan tidak mendapatkan tekanan dalam pemberitaan. Narasumber yang berasal dari pemerintah RI tidak menjadi sumber utama pemberitaan media. Meski begitu ekspektasi publik sejalan dengan pernyataan pemerintah RI, politikus dan opini media.

Objektifitas media Indonesia dalam memberitakan konflik Israel-Palestina yang mendasarkan pada opini professional fokus pada konten informatif. Sementara itu pemberitaan media di Indonesia tidak mengikuti objektifitas berdasarkan etika jurnalistik dengan tidak menampilkan keberimbangan, dan pemberitaan menunjukkan keberpihakan.

Riset ini mengeksplorasi objektifitas media dalam memberitakan konflik Israel-Palestina dengan menunjukkan bahwa terdapat negosiasi terhadap etika jurnalistik yang dilakukan media di Indonesia. Praktik jurnalistik mengikuti perkembangan geopolitik bukanlah studi baru, namun hasil penelitian ini memberikan kontribusi pada studi media yang tengah berkembang seiring perkembangan Internet dan media sosial khususnya di Indonesia. Penelitian ini merupakan studi kasus yang dilakukan terhadap tiga media siber nasional Indonesia dengan waktu penelitian yang terbatas sehingga tidak memenuhi kriteria untuk dilakukan generalisasi. Studi ini menyarankan penelitian terhadap lebih banyak sampel media baik lokal maupun nasional.

\section{DAFTAR PUSTAKA}

Adeyemo, J. A. (2020). Evaluation Of Media Performance And Objectivity in Newsreporting. Crutech Journal of Communication, 2(2), 35-43. https://www.crutech.edu.ng/index.php/ cjc-2-2/386-evaluation-of-media-performanceand-objectivity-in-newsreporting-by-juliusabioye-adeyemo-ph-d

Ambardi, K., Parahita, G. D., Lindawati, L., \& 
Sukarno, A. (2018). Kualitas jurnalisme publik di media online. Yogyakarta: UGM Press.

Anggoro, A. S. (2012). Detikcom: Legenda media online. MocoMedia.

Bourdieu, P. (2005). The Political Field, the Social Science Field, and the Journalistic Field. In R. Benson \& E. Neveu (Eds.), Bourdieu and the Journalistic Field (pp. 29-47). Politi Press.

Bryman, A. (2012). Social Research Methods. Oxford University Press.

Bryman, A. (2016). Social research methods. Oxford university press.

Butsch, R. (2007). Introduction: How are media public spheres? In Media and public spheres (pp. 1-14). Springer.

Carlson, M. (2019). News algorithms, photojournalism and the assumption of mechanical objectivity in journalism. Digital Journalism, 7(8), 1117-1133.

Charles, M. (2019). Advocacy Journalism. The International Encyclopedia of Journalism Studies, 1-5.

CNN Indonesia. (2021). Full: Pidato Menlu RI, Israel Perlu Ditekan Supaya Bisa Negosiasi. https:// www.youtube.com/watch?v=pJwcx39b0KM

Djuyandi, Y., Prawira, I., \& Irawan, R. E. (2017). Media neutrality in indonesian presidential election 2014. Advanced Science Letters, 23(5), 4816-4819.

Dwiastuti, I. (2021). The Roots of Israel-Palestine Conflict: A Political Culture Analysis. AEGIS: Journal of International Relations, 4(2), 1933. https://doi.org/http://dx.doi.org/10.33021/ aegis.v4i2.796

Eddyono, A. S. (2020). Menelusuri Praktik Search Engine Optimazation (SEO) di Media Siber dan Dampaknya bagi Jurnalisme (Studi pada Kompas. com, Tempo. co, Tirto. id, dan Liputan6. com). Universitas Bakrie.

Erwanti, M. O. (2021). Jokowi Desak PBB Tindak Israel: Indonesia Stand With The People of Palestine. Detik.Com. https://news.detik. com/berita/d-5564827/jokowi-desak-pbbtindak-israel-indonesia-stand-with-thepeople-of-palestine

Fisilla, I. A. (2021). Construction of "Objectivity" in Translated Pikiran Rakyat News Report. Thirteenth Conference on Applied Linguistics (CONAPLIN 2020), 233-238.

Fong, Y. L., \& Ponnan, R. (2019). Framing the bilateral relations between Malaysia and China: The news coverage of flight MH370. SEARCH Journal of Media and Communication Research, 11(1), 63-81.

Fuchs, C., \& Sandoval, M. (2015). The Political Economy of Capitalist and Alternative Social Media. In C. Atton (Ed.), The Routledge Companion to Alternative and Community Media (pp. 165-176). Routledge.

Ghazali, E. (2004). Interaksi politik dan media: dari komunikasi politik ke politik komunikasi. Jurnal Ilmu Sosial Dan Ilmu Politik, 8(1), 53-74.

Ghazali, E. (2011). Menuntut kelengkapan peran media: Tidak hanya membawa tetapi juga membongkar pencitraan. Jurnal Ilmu Sosial Dan Ilmu Politik, 14(3), 275-296.

Hadiansyah, S. (2021). Di Indonesia, Donasi untuk Palestina Terkumpul Rp 5 Miliar dalam 2 Hari. Liputan6.Com. https://www.liputan6. com/showbiz/read/4558150/taqy-malik-takmenyangka-donasi-untuk-palestina-tembusrp-5-miliar-dalam-2-hari

Hayes, A. F., \& Krippendorff, K. (2007). Answering the call for a standard reliability measure for coding data. Communication Methods and Measures, 1(1), 77-89.

Indonesia.go.id. (n.d.). Indonesia Profil Agama.

Kperogi, F. A. (2013). News with views: Postobjectivism and emergent alternative journalistic practices in America's corporate news media. Review of Communication, 13(1), 48-65.

Kumparan. (2021). Siswi SMA di Bengkulu Dikeluarkan dari Sekolah Usai Unggah Video Hina Palestina. https:/kumparan. com/kumparannews/siswi-sma-di-bengkuludikeluarkan-dari-sekolah-usai-unggah-videohina-palestina-1vm2LqpxKSc

Lestari, S. (2018). Mengenal komunitas Yahudi di Indonesia. BBC Indonesia. https://www.bbc. com/indonesia/indonesia-42422076

Margianto and Syaefullah. (2012). Media Online: Pembaca, Laba, dan Etika. https://aji.or.id/ $\mathrm{read} / \mathrm{buku} / 15 /$ media-online-pembaca-labadan-etika.html

Margianto, H. (2010). Inilah "Kedubes Israel" untuk Indonesia. Kompas.Com. https://tekno.kompas. com/read/2010/10/25/12000762/Inilah..quot. Kedubes.Israel.quot..untuk.Indonesia

Margiyono. (2009). Membangun Benteng Kebebasan: 
Seri Reformasi Kebijakan Media. Aliansi Jurnalis Independen (AJI) Indonesia.

McNair, B. (2011). An introduction to political communication. Routledge.

McQuail, D., \& Windahl, S. (2015). Communication models for the study of mass communications. Routledge.

Mothes, C. (2017). Biased objectivity: An experiment on information preferences of journalists and citizens. Journalism \& Mass Communication Quarterly, 94(4), 1073-1095.

Muslikhin, M., Mulyana, D., Hidayat, D. R., \& Utari, P. (2021). The Commodification, Spatialization and Structuration of Social Media in the Indonesian Cyber Media News. Media and Communication, 9(2), 110-118.

Neuendorf, K. A. (2016). The Content Analysis Guidebook. In Sage Publication. SAGE.

Nurdiansyah, R. (2021). Wali Kota Depok Sumbang Rp 200 Juta untuk Palestina. Republika. https://www.republika.co.id/berita/ qtcuem384/wali-kota-depok-sumbang-rp200-juta-untuk-palestina

Nygaard, S. (2019). The appearance of objectivity: How immigration-critical alternative media report the news. Journalism Practice, 13(10), 1147-1163.

Pasandaran, C. C., \& Mutmainnah, N. (2020). Young Adults' Recognition of Native Advertising Disguised as News. Young Consumers, 2l(1), 91-108. https://doi.org/https://doi. org/10.1108/YC-08-2019-1032

Prabawati, G. (2021). Nasib 5 Netizen Indonesia yang MenghinaPalestina, Diviralkan Melly Goeslaw hingga Dipenjara. Tribun News. https:// www.tribunnews.com/regional/2021/05/20/ nasib-5-netizen-indonesia-yang-menghinapalestina-diviralkan-melly-goeslaw-hinggadipenjara?page $=2$

Prawira, I. (2019). Political news construction in postauthoritarian Indonesia: citizen journalism in online news media during the 2017 election. Northumbria University.

Prawira, I. (2020). Praktik Jurnalisme Menghadapi Krisis Ganda; Studi Ranah Jurnalistik Media di Indonesia pada Masa Kenormalan Baru. In L. Yudhi (Ed.), Adaptasi Disiplin Ilmu Komunikasi di Masa Normal Baru (pp. 279 292). CV. Putra Media Nusantara (PMN).

Prawira, I., \& Irawan, R. E. (2020). Competition For Public Influencer In The New Democratic Era (Online News Media Strategy In
Monopolising Political Communication. Hamdard Islamicus, 43(S.2), 1787-1802.

Prawira, I., \& Rizkiansyah, M. (2018). Search Engine Optimization in News Production Online Marketing Practice in Indonesia Online News Media. Pertanika Journal of Social Sciences \& Humanities, 26(1), 263-270.

Ramasubramanian, S., \& Miles, C. (2018). Framing the Syrian Refugee Crisis: A Comparative Analysis of Arabic and English News Sources. International Journal of Communication, 12, 4488-4506.

Rauch, J. (2016). Are there still alternatives? Relationships between alternative media and mainstream media in a converged environment. Sociology Compass, 10(9), 756-767.

Rietdijk, N., \& Archer, A. (2021). Post-Truth, False Balance and Virtuous Gatekeeping. In N. Snow \& M. S. Vaccarezza (Eds.), Virtues, Democracy, and Online Media: Ethical and Epistemic Issues. Routledge.

Rijkers, M. (2020). Sejak Kapan Israel Menjajah Palestina? Kompasiana. https://www.kompasiana.com/ niquerijkers/5b93c780aeebe11abf142f93/ sejak-kapan-israel-menjajah-palestina

Robin, N. (2014). False Balance in Climate Reporting Reveals BBC's Sensitivity to Political Pressure. London School of Public Economics and Politics; London School of Economics and Political Science. https:// blogs.1se.ac.uk/medialse/2014/04/02/ false-balance-in-climate-reportingreveals-bbcs-sensitivity-to-politicalpressure/

Sadewo, J. (2021). Wakil Ketua MPR: Membela Palestina Itu Perintah Konstitusi. Republika.

Sasongko, A. (2021). PMI Salurkan Donasi Rp1 miliar untuk Palestina. Republika. https:// www.republika.co.id/berita/qtcvug313/ pmi-salurkan-donasi-rp1-miliar-untukpalestina

Sen, K., \& Hill, D. T. (2007). Media, culture and politics in Indonesia. Equinox Publishing.

Setiawan, A. (2020). Media Online Perlu Berbenah Diri. Medcom. https://www. medcom.id/pilar/kolom/Wb70Wyakmedia-online-perlu-berbenah-diri

Shadiqi, M. A., Muluk, H., \& Milla, M. N. 
(2020). Support for Palestine Among Indonesian Muslims: Religious Identity and Solidarity as Reasons for E-Petition Signing. Psychological Research on Urban Society, 3(1), 40-51. https://doi. org/http://doi.org/10.7454/proust.v3i1.83

Swanson, D. L. (2005). Political news in the changing environment of political journalism. In Political Communication in a New Era (pp. 19-39). Routledge.

Tapsell, R. (2012). Old tricks in a new era: Selfcensorship in Indonesian journalism. Asian Studies Review, 36(2), 227-245.

Tapsell, R. (2015). Indonesia's media oligarchy and the "Jokowi phenomenon." Indonesia, 99, 29-50.

Trilling, D., Tolochko, P., \& Burscher, B. (2017). From newsworthiness to shareworthiness: How to predict news sharing based on article characteristics. Journalism \& Mass
Communication Quarterly, 94(1), 38-60.

Trussler, M., \& Soroka, S. (2014). Consumer demand for cynical and negative news frames. The International Journal of Press/Politics, 19(3), 360-379.

Westerståhl, J. (1983). Objective news reporting: General premises. Communication Research, 10(3), 403-424.

Wu, H. D., Sylvester, J., \& Hamilton, J. M. (2002). Newspaper provides balance in Palestinian/Israeli reports. Newspaper Research Journal, 23(2-3), 6-17.

Yangyue, L. (2014). Transgressiveness, civil society and Internet control in Southeast Asia. The Pacific Review, 27(3), 383-407.

Yusuf,A.M.(2016). Metode penelitian kuantitatif, kualitatif \& penelitian gabungan. Prenada Media. 